\title{
Flora da Reserva Ducke, Amazonas, Brasil: Rhamnaceae
}

Rita Baltazar de Lima ${ }^{1}$

Ducke, A. 1935. Plantes nouvelles ou peu connues de la région amázonienne; Ampelozizyphus Ducke n. gen. Arch. Inst. Biol. Veg. 2(2):157-158. pl. 1-2.

Macbride, J. F. 1956. Flora do Perú. Field Mus. Nat. Hist. 13(3A;2): 391-408.

Reissek, S. 1861. Rhamnaceae. In: C. P. Martius \& A. W. Eichler (eds.). Fl. bras. 11(1): 81-116.

Suessenguth, K. 1953. Rhamnaceae. In: A. Engler \& K. Prantil. Die Natürlichen Pflanzenfamilien. Berlin. 173p.

Richardson, J. E., Fay, M. F., Cronk, Q. C. B., Bowman, D. \& Chase, M. W. 2000. A phylogenetic analysis of Rhamnaceae using rbcL and trnL-F plastid DNA sequences. Amer. J. Bot. 87(9): 1309-1324.

Rodriguez-Carraquero, H. A. 1980. Studies in Rhamnaceae II. Ampelozizyphus amazonicus Ducke in Venezuela. Phytologia 45(3): 285-286.

Árvores, arbustos, ervas ou lianas, inermes ou espinescentes. Folhas simples, alternas ou opostas, pecioladas ou sésseis, rudimentares ou ausentes; lâmina ovalada a elíptica, base cordada, obtusa ou aguda, ápice acuminado, agudo ou obtuso, margem inteira, crenada, serreada ou denteada, membranácea, cartácea ou coriácea, trinérvea a peninérvea. Estípulas laterais ou intrapeciolares, decíduas. Inflorescências axilares ou terminais, em dicásios, tirsos, umbelas ou fascículos. Flores pediceladas ou sésseis, diclamídeas, pentâmeras, actinomorfas, monoclinas e/ou diclinas estaminadas; cálice com sépalas triangulares, face adaxial com nervura mediana proeminente e ápice caloso, prefloração valvar; pétalas membranáceas, unguiculadas ou sésseis, convolutas, cuculadas ou conchiformes, prefloração aberta; estames 5 , livres, opostos às pétalas, anteras ditecas, dorsifixas, sub-rotundas a oblongas, latrorsas; disco nectarífero crasso ou membranáceo, glabro a velutino; ovário súpero a ínfero, glabro a velutino, 2-3-carpelar, 2-3-locular, um óvulo por lóculo, placentação basal; estiletes 2-3, livres ou unidos, glabros ou pubescentes; estigmas 1-3. Frutos drupáceos, capsulares ou esquizocarpos, alados ou não. Sementes geralmente elipsóides, castanhas, brilhantes.

Família cosmopolita com ca. 58 gêneros e 900 espécies, dos quais ca. 28 gêneros e 170 espécies ocorrem na região neotropical.

\section{Ampelozizyphus}

Ampelozizyphus Ducke, Arch. Inst. Biol. Veget. 2(2): 157. 1935.

Gênero monoespecífico, endêmico da Amazônia.

1.1 Ampelozizyphus amazonicus Ducke, Arch. Inst. Biol. Veget. 2(2): 158. 1935.

Fig. 1

Lianas robustas, inermes, sem gavinhas; caule cilíndrico, estriado, ferrugíneo, lenticelado lenticelas acastanhadas. Folhas grandes, alternas, pecioladas, ovaladas a oblongas, coriáceas; lâmina 10-22 × 6,2$11 \mathrm{~cm}$, base arredondada ou obtusa, ápice agudo, margem inteira, revoluta, face adaxial glabra, abaxial pubérula a glabrescente, $3(-5)$ nervuras proeminentes nas duas faces, partindo $0,3-0,5 \mathrm{~cm}$ da base; pecíolo $1,3-$ $2,5 \mathrm{~cm}$ compr., cilíndrico, sulcado ventralmente. Estípulas laterais, precocemente decíduas. Inflorescências multifloras, ferrugíneas, em tirsos laxos, axilares ou terminais, raque $42-$ $50 \mathrm{~cm}$ compr.; brácteas folhosas, 2,7-6,3 $\times$ 1,3-3,3 cm, pecíolo 0,4-1 cm compr., pubérulas. Flores crassas, monoclinas, 3$4 \mathrm{~mm}$ compr.; pedicelo 1-2 mm compr.; sépalas 1,1-1,5 × 1,2-1,4 mm; pétalas ca. $1,5 \mathrm{~mm}$ compr., conchiformes, unguiculadas, unhas laminares, longas, $0,4-0,5 \mathrm{~mm}$ compr.; estames ca. $1 \mathrm{~mm}$ compr., filetes crassos, achatados; anteras ca. $0,3 \mathrm{~mm}$ compr.; disco nectarífero crasso, crenado, glabro; ovário 


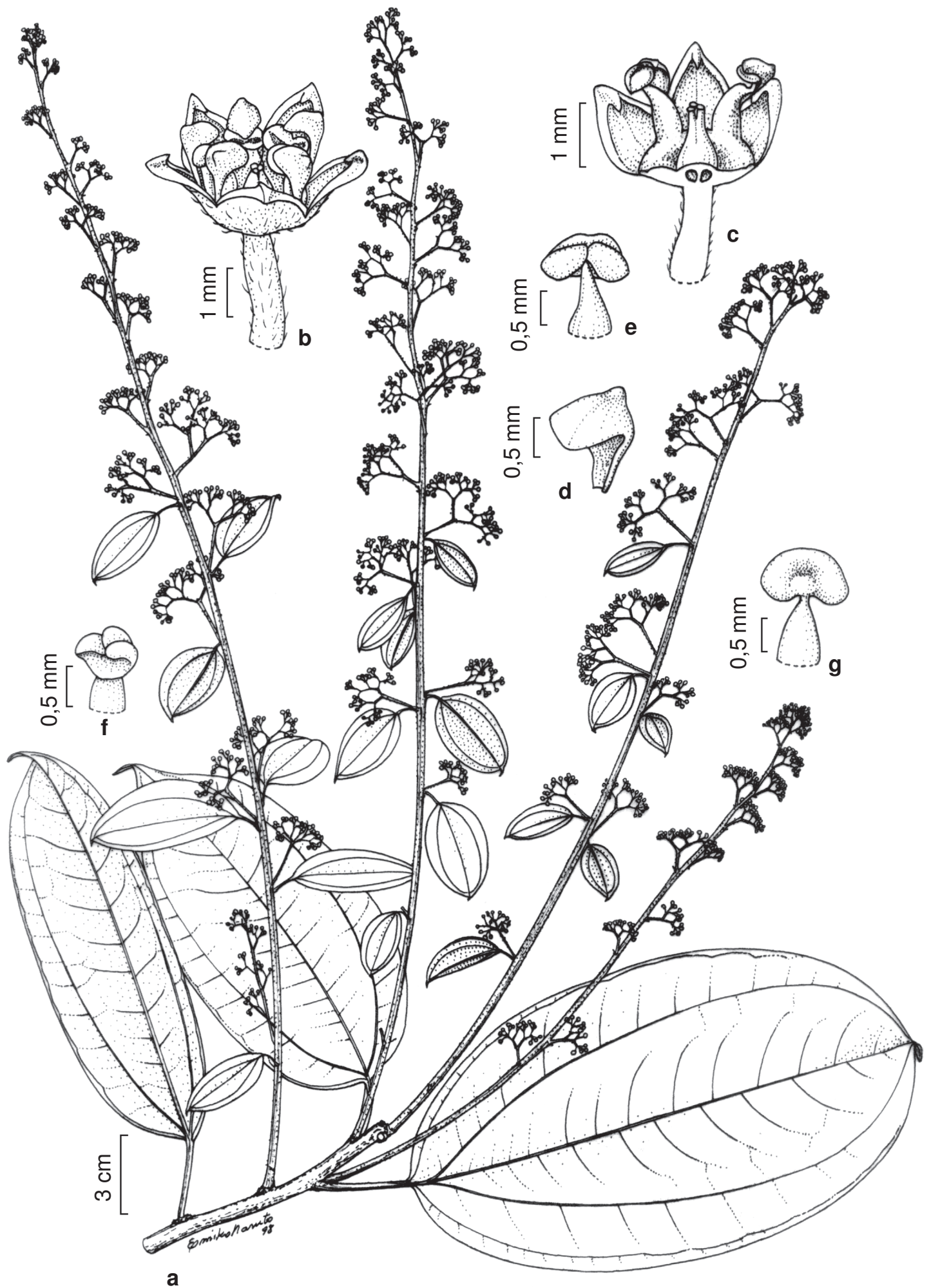

Figura 1 - Ampelozizyphus amazonicus: a. hábito; b. flor inteira; c. flor em corte logitudinal; d. pétala; e-g. estame (M. A. D. Souza \& C. F. Silva 163). 
semi-ínfero, 3-carpelar, 3-locular, 3 óvulos, um em cada lóculo; estiletes 3, crassos, curtos, livres apenas no ápice; estigmas obtusos. Frutos capsulares, obovados, angulosos, glabros; frutos imaturos ca. $2 \mathrm{~cm}$ compr., pedicelo ca. 0,5 cm compr. Sementes ovaladas, castanhas, brilhantes, 1,2-1,3 $\times 1 \mathrm{~cm}$.

A espécie é endêmica da América do Sul, com distribuição na amazônia brasileira, venezuelana, colombiana e peruana, expandindo-se até o Equador. No Brasil, ocorre nos estados do Amazonas, Pará e Roraima, sendo encontrada em florestas de terra firme.

Floresce de outubro a dezembro e frutifica de novembro a fevereiro.

Nome regional: saracura-mirá, cervejeira. 8.II.1996 (fr) Lima, R. et al. 1359 (INPA K MG NY SPF); 9.II.1996 (fr) Lima, R. et al. 1360 (INPA); 13.XI.1997 (fl) Martins, L. H. P. \& Silva, C. F. 58 (G INPA K MBM MG SPF); 19.XI.1997 (fl) Ribeiro, J. E. L. S. et al. 1949 (IAN INPA K MO RB SPF U UB); 3.I.1969 (fl) Souza, J. A. 309 (INPA); 16.XI.1995 (fl) Souza, M. A. D. \& Silva, C. F. 163 (BM INPA K PUEFR SPF UEC UFMT US VEN); 18.XII.1997 (fl) Souza, M. A. D. et al. 515 (INPA K NY SPF); 8.XII.1993 (fl) Vicentini, A. et al. 392 (INPA K MG NY SPF); 1.XI.1995 (fl) Vicentini, A. et al. 1117 (G INPA K MG MO RB SP SPF U).

Ampelozizyphus é um gênero monoespecífico, originalmente descrito por Ducke (1935), que o incluiu na tribo Zizypheae. Posteriormente, Suessenguth (1953), considerando a morfologia do fruto, o transferiu para a tribo Rhamneae. Mais recentemente, Richardson et al. (2000), estudando a filogenia da família Rhamnaceae, com base em sequenciamento molecular, propuseram a inclusão de uma nova tribo nesta família, a tribo Ampelozizypheae, para melhor posicionar este gênero.

A espécie Ampelozizyphus amazonicus possui potencial medicinal, que tem sido utilizado na medicina popular. A infusão da raspa da raiz é usada na região amazônica para a cura de resfriado e da malária. 